\title{
Nostoc calcicola extract improved the antioxidative response of soybean to cowpea aphid
}

\author{
Van-Chung Mai ${ }^{1 *} \mathbb{D}$, Ba-Hoanh Nguyen ${ }^{1}$, Duc-Dien Nguyen ${ }^{2}$ and Le-Ai-Vinh Nguyen ${ }^{2}$
}

\begin{abstract}
Background: Soybean (Glycine max (L.) Merr. CV. "Nam Dan”) is one of the most valuable crops in agricultural production in Nghe An province (Vietnam). Our previous study revealed that extract of the cyanobacterium strain Nostoc calcicola HN9 expressed positive effect on growth and development, and raised soybean productivity (Tran et al. in Proceeding of Vietnam national conference of research on biology, Da Nang, 2016). We hypothesized that N. calcicola HN9 would improve the defense responses of G. max cv. "Nam Dan" to cowpea aphid (Aphis craccivora Koch)-a serious pest of leguminous crops.

Results: Infestation of A. craccivora caused oxidative stress in leaves of G. max Cv. "Nam Dan". A strong generation of endogenous reactive oxygen species (ROS) such as superoxide anion radical $\left(\mathrm{O}_{2}^{--}\right)$and hydrogen peroxide $\left(\mathrm{H}_{2} \mathrm{O}_{2}\right)$ resulted in the cellular damages in the aphid-infested leaves through high levels of injury percentage and lipid peroxidation. To protect from aphid attack themselves, soybean plants triggered the antioxidant defense systems, in which, enzymatic antioxidants such as superoxide dismutase (SOD, 1.15.1.1), catalase (CAT, 1.11.1.6) and GPx (EC 1.11.1.9) were strongly accumulated to reduce the toxic effects of ROS. Components of N. calcicola HN9 extract might strengthen the defensive capability of G. max cv. "Nam Dan" to cowpea aphid infestation via establishing the chemical constraints on oxidative stress. Under effect of cyanobacteria extract, generation of $\mathrm{O}_{2}^{--}$and $\mathrm{H}_{2} \mathrm{O}_{2}$ was strictly limited, activities of SOD, CAT and GPx were remarkably accumulated in the aphid-infested leaves leading to a significant reduction of oxidative damages.

Conclusions: Nostoc calcicola HN9 extract probably not only controlled the generation and effects of $\mathrm{O}_{2}^{--}$and $\mathrm{H}_{2} \mathrm{O}_{2}$ but also augmented the accumulated activity of SOD, CAT and GPx in soybean leaves that allowed them to control oxidative stress, contributed to increase the resistance of G. max CV. "Nam Dan" to A. craccivora. The improvement of cyanobacteria extract on the antioxidative response of soybean "Nam Dan" to cowpea aphid can be a novel aspect to contribute to current knowledge regarding the soybean-aphid interaction.
\end{abstract}

Keywords: Aphis craccivora, Glycine max, Nostoc calcicola HN9, Hydrogen peroxide, Superoxide anion radical, Catalase, Glutathione peroxidase, Superoxide dismutase

\section{Background}

Cyanobacteria (or blue-green algae) are the large group of prokaryotic, photosynthetic microorganisms, which are a rich source of potentially various bioactive compounds effecting on living organisms (Zulpa et al. 2003).

\footnotetext{
*Correspondence: chungmv@vinhuni.edu.vn

1 Department of Plant Physiology, School of Natural Sciences Education, Vinh University, str. Le Duan 182, Vinh, Nghe An Province, Vietnam Full list of author information is available at the end of the article
}

The endogenous substances in cyanobacteria, e.g., vitamins, enzymes, carbohydrates, amino acids, have been known to induce crop growth and raise yields (Shariatmadari et al. 2013; Prasanna et al. 2013). Other natural products from cyanobacteria like carotenoids, phenolic compounds, etc., exhibit various biological effects such as cytotoxic, antibacterial and antifungal activities (Kulik 1995; Zulpa et al. 2003). Therefore, an inoculation with cyanobacteria not only promotes plants growth but 
also enhances their defense responses (Rana et al. 2012; Prasanna et al. 2013).

Nostoc, an unbranched filamentous cyanobacterium genus (Komárek 2010), has been regarded as good candidate for producing secondary substances that can effect on living organisms (Hirata et al. 2003). Treating Solanum lycopersicum, Cucurbita maxima, Cucumis sativus plants with Nostoc calcicola extracts revealed a significant positive effect in most physiological examined factors (Shariatmadari et al. 2011). The similar results were also confirmed by studies on other crops such as rice (Saadatnia and Riahi 2009), maize (Jäger et al. 2010). Several substances in Nostoc spp. expressed the antifungal, antibacterial, antiviral or cytotoxic activities on crops (Nowruzi et al. 2012). Nostocine A exhibited strong inhibitory activity to the root elongation of barnyard grass, high antifeedant activity to cotton ballworm, and acute toxicity to mice resulting in its classification as a dangerous poison (Hirata et al. 2003). Extract of Nostoc $\mathrm{sp}$. induced oxidative stress by accumulating reactive oxygen species (ROS), causing massive cell death in Mimosa pigra (Sukkhaeng et al. 2015). Contrary, an in vitro study of Li and co-workers (2007) demonstrated that Nostoc species have their ability to scavenge ROS and inhibit lipid peroxidation.

Reactive oxygen species such as superoxide anion radical $\left(\mathrm{O}_{2}^{--}\right)$, hydrogen peroxide $\left(\mathrm{H}_{2} \mathrm{O}_{2}\right)$ are produced as a normal product of plant cellular metabolism. Despite their destructive activity, they are well-described second messengers in a variety of cellular processes, including conferment of tolerance to various stresses. Whether ROS would serve as signaling molecules or could cause oxidative damage to the tissues depends on the delicate equilibrium between ROS productions, and their scavenging (Sharma et al. 2012). In plants tissues affected by aphid attack, $\mathrm{O}_{2}^{--}$and $\mathrm{H}_{2} \mathrm{O}_{2}$ are often enhanced in apoplastic as well as in symplastic regions, besides their main concentration in exocellular matrix, peroxisomes/ mitochondria and plasma membrane (Smith and Boyko 2007; Maffei et al. 2007). High level of those ROS can exert toxic effects, and their uncontrolled productions can damage cellular components and associated loss of function leads to cell death (Ahmad et al. 2008). Plants have the efficient complex antioxidant defense systems to avoid the toxic effects of ROS, including enzymatic antioxidants such as superoxide dismutase (SOD), catalase (CAT), peroxidases (POX) and others (Maffei et al. 2007; Ahmad et al. 2008). Functions of those enzymatic antioxidants in plant defense responses have been reported in several plant-aphid interactions. Enhanced activity of SOD and CAT was suggested as one of the most essential elements of defense responses in pea seedling to oxidative stress caused by infestation of pea aphid (Mai et al.
2013). Accumulation of POX was strongly enhanced in wheat after feeding of the Russian wheat aphid (Moloi and van der Westhuizen 2006; Ni et al. 2001), in response of soybean to cowpea aphid (Mai et al. 2016). In cabbage plants, activities of polyphenol peroxidase and polyphenol oxidase were stimulated by cabbage aphid infestation (Khattab 2007). However, up to date, lack information has been mentioned about effects of cyanobacteria on plant antioxidant defense systems against aphid impacts.

Soybean (Glycine $\max$ (L.) Merr. cv. "Nam Dan") is an important crop in the agricultural production in Vietnam for its edible seed as the foremost material of vegetative protein and oil used in the food processing. During its life, soybean plant has to face to attack from cowpea aphid (Aphis craccivora Koch)-one of the most destructive aphid species of leguminous crops. Our previous study (Tran et al. 2016) revealed that inoculation extract of the cyanobacterium strain $N$. calcicola HN9 presented the positive effect on growth, development and productivity of soybean "Nam Dan". The aim of present work was to investigate effects of $N$. calcicola HN9 extract on the antioxidative responses of G. max cv. "Nam Dan" when soybean plants were cultured in Hoagland medium in phytotron, infested by different density of cowpea aphid in different time intervals. Cytochemical localization and the alteration in contents of $\mathrm{O}_{2}^{--}, \mathrm{H}_{2} \mathrm{O}_{2}$ as well as changes in activity of antioxidant enzymes such as SOD (EC 1.15.1.1), CAT (EC 1.11.1.6), and GPx (EC 1.11.1.19) in soybean leaves were carefully assessed. As a secondary objective, degree of cellular oxidative damages was investigated on measurement of the electrolyte leakage and levels of thiobarbituric acid reactive substances (TBARS)-a final product of lipid peroxidation. It is worth noting that the aforementioned aspects will provide the additionally convinced evidences to clarify whether G. $\max$ cv. "Nam Dan" is an aphid resistant cultivar of soybean.

\section{Methods \\ Cyanobacteria culture and extraction}

The cyanobacterium strain, N. calcicola HN9 (voucher specimen is deposited at herbarium of the Phycology lab, Vinh University), was collected from the rice field in Hung Nguyen district (Nghe An province, Vietnam) and isolated by the streak plate method. Nostoc cells were cultured in BG11 medium, pH 6.5 at ambient temperature $\left(25 \pm 2{ }^{\circ} \mathrm{C}\right)$, light intensity of $110-130 \mu \mathrm{M}$ photons $\mathrm{m}^{-2} \mathrm{~s}^{-1}$, light period of 14 light/10 dark (Rippka et al. 1979).

The cyanobacteria biomass in the cultured day of 23th (in the stationary phase) was harvested, centrifuged at $6000 \times g$ for $15 \mathrm{~min}$, and subsequently dried at $55^{\circ} \mathrm{C}$ for $72 \mathrm{~h}$. The dried cells were ground to powder, and 
extracted with $80 \%$ methanol for $24 \mathrm{~h}$ at ambient temperature. Supernatant was collected after centrifuging by $10,000 \times g$ for $15 \mathrm{~min}$, then evaporated to obtain a crude brown gum. This gum was dissolved in the deionized water to the concentration of $0.03 \%$, which expressed the positive effect to growth of soybean "Nam Dan" (Tran et al. 2016).

\section{Plant and inoculation experiment}

Experiments were performed on soybean (Glycine max (L.) Merr. cv. "Nam Dan") plants whose seeds were exclusively supplied by Nghe An seed center (Vietnam). Seeds were surface-sterilized by $\mathrm{HgCl}_{2} 0.01 \%$ for $10 \mathrm{~min}$ and then were imbibed in the incubator at $23 \pm 1{ }^{\circ} \mathrm{C}$ for $48 \mathrm{~h}$. Germinating seeds were cultured in $10 \mathrm{~cm}$ diameter plastic pots (one plant per pot) containing Hoagland medium placed in phytotron with temperature of $23 \pm 1{ }^{\circ} \mathrm{C}$, relative humidity of $70-75 \%$, light intensity of $110-130 \mu \mathrm{M} \mathrm{m}^{-2} \mathrm{~s}^{-1}$ and light period 14 light/10 dark hours.

As growing in the V3 stage (first two trifoliate leaves fully developed, third trifoliate leaf unrolled), soybean plants were divided into two equal groups. The first one included soybean plants that were sprayed on the surface of leaves by $1 \mathrm{~mL}$ solution $N$. calcicola HN9 extract, concentration $0.03 \%$, per plant. The second one was soybean without cyanobacteria inoculation.

\section{Aphid and infestation experiment}

The aphid species used to treat soybean "Nam Dan" is cowpea aphid (Aphis craccivora Koch), which is obtained from Department of Applied Entomology (Vietnam Academy of Science and Technology). The virus free individuals were cultured on host, G. $\max$, in phytotron in temperature of $23 \pm 1{ }^{\circ} \mathrm{C}$, relative humidity of $70-75 \%$, light intensity of $110-130 \mu \mathrm{M} \mathrm{m}^{-2} \mathrm{~s}^{-1}$ and light period of 14 light/10 dark hours (Mai et al. 2016).

After spraying of $N$. calcicola HN9 extract $24 \mathrm{~h}$, all soybean plants in two mentioned groups were used for setting up experiments of infestation. Each soybean plant was separately treated by 10,20 or 30 wingless adults of $A$. craccivora. The similarly wingless adults of cowpea aphid were carefully selected and transferred to soybean leaves with a fine paintbrush. The newly produced nymphs and winged individuals were monitored daily to prevent density-dependent effects on aphid performance; therefore, number of wingless adults of A. craccivora in experiments was constant. Control was soybean plants without aphid infestation. The control and aphid-infested variants were separately put in glass boxes $(50 \mathrm{~cm} \times 50 \mathrm{~cm} \times 50 \mathrm{~cm})$ covered by nylon gauze; all were placed in the phytotron with the environmental factors such as temperature, related humidity, light intensity and light period controlled.

\section{Material for analysis}

Mature leaves of soybean plants in all variants were carefully collected at $0,6,12,24,48,72$ and 96 h post-infestation (hpi) of cowpea aphid. Aphid individuals all were removed; leaves were weighed, frozen in nitrogen liquid and kept at $-20{ }^{\circ} \mathrm{C}$ for subsequent analyses of lipid peroxidation and activity of antioxidant enzymes. Content and cytochemical localization of superoxide anion radical $\left(\mathrm{O}_{2}^{--}\right)$, hydrogen peroxide $\left(\mathrm{H}_{2} \mathrm{O}_{2}\right)$ and injury percentage were determined in fresh materials.

\section{Determination of superoxide anion radical content}

Content of superoxide anion radical $\left(\mathrm{O}_{2}^{--}\right)$was determined following the nitro blue tetrazolium (NBT) assay (Doke 1983). Soybean leaves (0.30 g fresh weight-FW) were incubated in $3 \mathrm{~mL}$ of $10 \mathrm{mM}$ phosphate buffer $(\mathrm{pH}$ 7.8) containing $0.05 \% \mathrm{NBT}$ and $10 \mathrm{mM} \mathrm{NaN}_{3}$ at ambient temperature for $1 \mathrm{~h}$. After incubation, the reacted solution was heated at $85^{\circ} \mathrm{C}$ for $15 \mathrm{~min}$, then rapidly cooled. Measurements were carried out in the UV-Vis CARY 60 spectrophotometer (Agilent, USA) connected with a computer; the spectral data were analyzed by using the UV-Win 5.0 application software. Content of $\mathrm{O}_{2}^{--}$was expressed as absorbance at $580 \mathrm{~nm}$ per $1 \mathrm{~g}$ fresh materials $\left(\mathrm{A}_{580} \mathrm{~g}^{-1} \mathrm{FW}\right)$.

\section{Detection of superoxide anion radical localization}

The cytochemical localization of $\mathrm{O}_{2}^{--}$was detected following method using dihydroethidium (DHE), the specific fluorescent dye, described by Morkunas and Bednarski (2008) with minor modification. The fresh soybean leaves were submerged in $50 \mathrm{M}$ DHE in $5 \mathrm{mM}$ DMSO after immersing $12 \mathrm{~h}$ in darkness at ambient temperature. After rinsing with the $100 \mathrm{M} \mathrm{CaCl}_{2}$ solution $\mathrm{pH} 5.0$, the DHE dying leaves were observed by using a Zeiss Axiovert $200 \mathrm{M}$ fluorescence microscope (model LSM 510, filter set no. 9, excitation 450-490 nm, emission $520 \mathrm{~nm}$ or more), magnified $5 \times$ and photographed by a digital camera (AxioCam, Zeiss). An argon laser with excitation at $488 \mathrm{~nm}$ and emission at 565-615 nm was used. Microscope, laser and photomultiplier settings were held stably during experiments to obtain comparable data. Images were analyzed by the LSM Image Browser software, version 4.2.

\section{Determination of hydrogen peroxide concentration}

Concentration of endogenous hydrogen peroxide $\left(\mathrm{H}_{2} \mathrm{O}_{2}\right)$ was determined following the spectrophotometric method (Becana et al. 1986) that was modified by Mai et al. (2013). $0.50 \mathrm{~g}$ fresh material were homogenized 
at $4{ }^{\circ} \mathrm{C}$ with $3 \mathrm{~mL}$ of $5 \%$ trichloroacetic acid (TCA) and $0.10 \mathrm{~g}$ activated charcoal. The homogenate was centrifuged at $12,000 \times g$ for $30 \mathrm{~min}$ at $4{ }^{\circ} \mathrm{C}$ to select supernatant using as extract. The reagent was prepared of $0.6 \mathrm{mM}$ 4-(-2 pyridylazo)resorcinol, $0.6 \mathrm{mM}$ of potassium-titanium oxalate in 1:1 proportion. Total $3 \mathrm{~mL}$ the reaction mixture contained extract, $100 \mathrm{mM}$ phosphate buffer $(\mathrm{pH} 8.4)$ and reagent. The decrease of absorbance was measured at wavelength of $508 \mathrm{~nm}$ in the UV-Vis CARY 60 spectrophotometer (Agilent, USA) system. The spectral data were analyzed by using the UV-Win 5.0 application software. Amount of hydrogen peroxide in soybean leaves was expressed as $\mathrm{M} \mathrm{H}_{2} \mathrm{O}_{2} \mathrm{~g}^{-1} \mathrm{FW}$.

\section{Detection of hydrogen peroxide localization}

Cytochemical localization of endogenous $\mathrm{H}_{2} \mathrm{O}_{2}$ generated in soybean leaves was detected by staining with specific fluorescence, the $2^{\prime}, 7^{\prime}$-dichlorofluorescein diacetate (DCFH-DA) following methods of Małecka et al. (2009) with minor modification. The fresh soybean leaves were submerged in $4 \mathrm{M} \mathrm{DCFH-DA} \mathrm{dissolved} \mathrm{in} 50 \mathrm{mM}$ potassium phosphate buffer ( $\mathrm{pH} 7.5)$ for $12 \mathrm{~h}$. Leaves were washed twice with the loading buffer and then were observed with the Zeiss LSM 510 confocal microscopy system. Fluorescence was excited using $488 \mathrm{~nm}$ of an argon laser with emission at 500-550 nm. All images were obtained at the same depth, and were analyzed by the LSM Image Browser software, version 4.2.

\section{Electrolyte leakage}

Electrolyte leakage was the conductometrical method used for assessing the injury percentage of cell membrane (Bajji et al. 2002). Five fresh, complete leaves of each sample were washed in deionized water for a few seconds, embedded in test-tubes containing $20 \mathrm{~mL}$ of deionized water and took the first conductometric measurement $\left(E C_{i}\right)$; then incubated on a shaking platform at ambient temperature for $3 \mathrm{~h}$ and measured again $\left(\mathrm{EC}_{\mathrm{f}}\right)$ by a conductivity meter (Orion Star A212, Thermo Scientific, USA). After autoclaving the solution at $100{ }^{\circ} \mathrm{C}$ for $20 \mathrm{~min}$ to rupture completely the membranes allowing ion leakage of the entire cell contents and cooling to ambient temperature, the third measurement was done $\left(\mathrm{EC}_{\mathrm{t}}\right)$. The membrane damage of soybean leaves' cells was evaluated as the injury percentage compared with control and was calculated as $I_{d}=\left[\left(R_{s}-R_{c}\right) /\left(1-R_{c}\right)\right] \times 100(\%)$; where $R_{s}$ and $R_{c}$ represent $\left(E C_{f}-E C_{j}\right) /\left(E C_{t}-E C_{i}\right)$ for aphid and/or cyanobacteria treated tissues and control, respectively.

\section{Lipid peroxidation}

The thiobarbituric acid reactive substances (TBARS) assay is the most generally used test in the appreciation of lipid peroxidation (Heath and Packer 1968). $0.50 \mathrm{~g}$ of frozen soybean leaves was homogenized in $3 \mathrm{~mL}$ of $0.5 \%$ thiobarbituric acid (TBA) in 20\% TCA and then centrifuged at $12,000 \times g$ for $20 \mathrm{~min}$ at $4{ }^{\circ} \mathrm{C}$ to select the extract. The reaction mixture [extract, phosphate buffer ( $\mathrm{pH} 7.0)$ and reagent $(0.5 \%$ TBA in $20 \%$ TCA, w/v)] were incubated at $95{ }^{\circ} \mathrm{C}$ for $30 \mathrm{~min}$ and then quickly cooled in an ice bath. After that, the mixtures were centrifuged at $10,000 \times g$ for $10 \mathrm{~min}$. The specific absorbance at $532 \mathrm{~nm}$ and the non-specific absorbance at $600 \mathrm{~nm}$ of the clear supernatant were measured by using the UV-Vis CARY 60 spectrophotometer. Level of lipid peroxidation was calculated and expressed as $\mu \mathrm{M}$ TBARS ${ }^{-1} \mathrm{FW}$.

\section{Enzyme assay}

Briefly, $0.50 \mathrm{~g}$ frozen soybean leaves were homogenized at $4{ }^{\circ} \mathrm{C}$ in $5.0 \mathrm{~mL}$ of $50 \mathrm{mM}$ phosphate buffer (pH 7.0) containing $1.0 \mathrm{mM}$ EDTA, $2 \% \mathrm{NaCl}$ and $1 \%$ polyvinyl pyrrolidone and centrifuged at $15,000 \times g$ for $15 \mathrm{~min}$ to select supernatant as the enzymatic extract.

Activity of SOD (EC 1.15.1.1) was spectrophotometrically assayed by measuring its ability in inhibition the photochemical reduction of NBT to a blue solution (Beauchamp and Fridovich 1971). The reacted mixture contained $50 \mathrm{mM}$ phosphate buffer ( $\mathrm{pH} 7.8), 13 \mathrm{mM}$ methionine, $75 \mathrm{mM}$ NBT, $0.1 \mathrm{mM}$ EDTA, enzymatic extract and $2 \mathrm{mM}$ riboflavin. The reaction was started by switching on a $30 \mathrm{~W}$ fluorescent lamp placed $30 \mathrm{~cm}$ above test-tubes and proceeded for $15 \mathrm{~min}$. Samples without the enzymatic extract were selected so that the absorption difference between blank and examined tests was about $50 \%$. Measurements were done by using the UV-Vis CARY 60 spectrophotometer. Amount of enzyme that caused the inhibition of NBT reduction by $50 \%$ was taken as a unit of SOD activity.

Activity of CAT (EC 1.11.1.6) was determined by measuring hydrogen peroxide removal (Dhindsa et al. 1981). The reacted mixture contained $100 \mathrm{mM}$ phosphate buffer ( $\mathrm{pH}$ 7.0), $3 \% \mathrm{H}_{2} \mathrm{O}_{2}$ and enzymatic extract. Absorbance was assessed by measuring at $240 \mathrm{~nm}$ against a calibration curve using the UV-Vis CARY 60 spectrophotometer.

Activity of GPx (EC 1.11.1.19) was assayed according to the procedure of Flohé and Günzler (1984) with minor modifications. The reaction mixture consisting of $0.5 \mathrm{~mL}$ of each: $0.4 \mathrm{M}$ sodium phosphate buffer ( $\mathrm{pH} 7.0$ ), $10 \mathrm{mM}$ sodium azide, $4 \mathrm{mM}$ reduced glutathione, $5 \mathrm{mM}$ $\mathrm{H}_{2} \mathrm{O}_{2}$, and enzyme extract was incubated at $0,30,60,90 \mathrm{~s}$ respectively. The reaction was terminated with $0.5 \mathrm{~mL}$ of $10 \%$ TCA and centrifuged; after that $2 \mathrm{~mL}$ of the supernatant was added to $3 \mathrm{~mL}$ of phosphate buffer and $1 \mathrm{~mL}$ of DTNB reagent (0.04\% DTNB in $1 \%$ sodium citrate). Absorbance was measured at a wavelength of $412 \mathrm{~nm}$ in the UV-Vis CARY 60 spectrophotometer. 
Activity of SOD, CAT and GPx was expressed as nanokatal per $1 \mathrm{mg}$ of protein (nkat $\mathrm{mg}^{-1}$ protein). The protein concentration in the samples was determined according to Bradford (1976) method by using bovine serum albumin as a standard.

\section{Statistical analysis}

Analyses all were performed at least in three independent experiments. Analysis of variance (ANOVA) was applied to verify whether means from independent experiments within each given variant were significant at level $\mathrm{P}<0.05$. Data shown in the figures are means and standard errors (s.e.), using asterisks to present the significant differences.

\section{Results}

\section{Generation of ROS in leaves of soybean "Nam Dan"}

Generally, a strongly release the reactive oxygen species (ROS) productions such as superoxide anion radical $\left(\mathrm{O}_{2}^{-}\right)$and hydrogen peroxide $\left(\mathrm{H}_{2} \mathrm{O}_{2}\right)$ was observed in aphid-infested leaves of soybean (Glycine max cv. "Nam Dan") in stage V3.

Without inoculating $N$. calcicola HN9 extract, superoxide anion radical in the aphid-infested leaves was remarkably released and reached to the highest content at $12 \mathrm{~h}$ post-infestation (hpi) of 10, 20, or 30 aphids, having values of 1.64-, 2.48-, and 2.63-fold higher than at the beginning, respectively. This ROS molecule then slightly reduced to lower levels until $96 \mathrm{hpi}$. Whereas, this free radical in control plants maintained at low level throughout the experiment (Fig. 1; the dash lines). ANOVA results showed the significant difference in levels of $\mathrm{O}_{2}^{-}$ in aphid-infested variants and control within 6-48 hpi.

Contrary, a small amount of $\mathrm{O}_{2}^{--}$was generated in leaves inoculated with $N$. calcicola HN9 extract, and content of this free radical was slightly increased from the beginning up to $96 \mathrm{hpi}$ (Fig. 1; the solid lines). In most of investigated time points, content of $\mathrm{O}_{2}^{--}$in soybean treated by $N$. calcicola HN9 extract was in lower than that in plant without cyanobacteria inoculating.

The applying confocal microscopy results revealed the relative release of $\mathrm{O}_{2}^{--}$in soybean leaves via DHE-fluorescence staining in epidermis cells surrounding the aphid feeding sites. DHE can passively cross the cells membrane, and is oxidized by $\mathrm{O}_{2}^{--}$to ethidium bromide that is detected by using the confocal laser scanning microscope. The fluorescence is proportional to the intracellular $\mathrm{O}_{2}^{--}$level. Figure 2 presented an example about the presence of $\mathrm{O}_{2}^{-}$at $12 \mathrm{hpi}$, in which time a burst of $\mathrm{O}_{2}^{--}$in aphid-infested/non cyanobacteria inoculated leaves was recorded by the spectrophotometric method. Cytochemical localization of $\mathrm{O}_{2}^{--}$presented that, a stronger intensity and larger surface area of the DHE-derived fluorescence

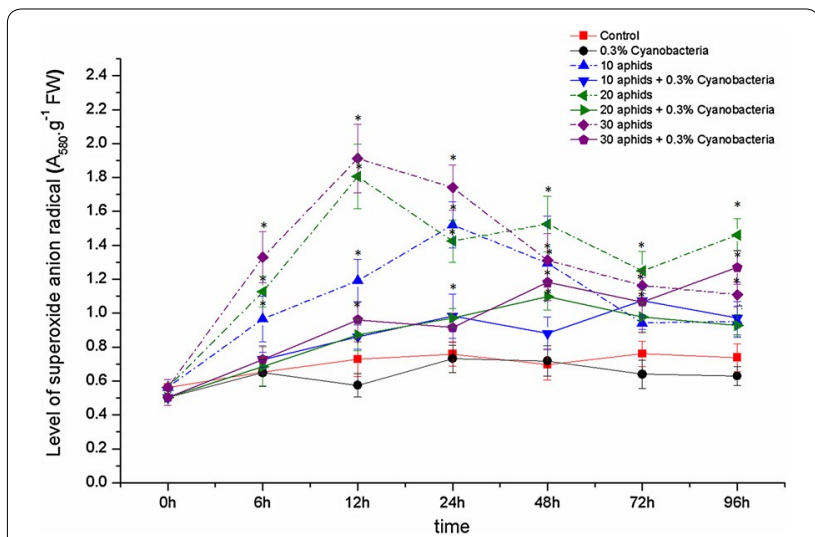

Fig. 1 Generation of superoxide anion radical $\left(\mathrm{O}_{2}^{-}\right)$in leaves of Glycine max cv. "Nam Dan" under infestation of Aphis craccivora and inoculation of Nostoc calcicola HN9 extract. Values represent means and s.e. from three independent experiments. $\left(^{*}\right)$ In figure shown the significant difference between the experimental variants and control at level $P<0.05$

appeared in leaves only infested by $A$. craccivora; while a small fluorescent stain was observed in the additionally inoculated cyanobacteria leaves. The fluorescent intensity also provided an important evidence that the release of $\mathrm{O}_{2}^{--}$was limited in soybean leaves inoculated by N. calcicola HN9 extract.

A strong generation and continuous increase of $\mathrm{H}_{2} \mathrm{O}_{2}$ in aphid-infested leaves was observed in soybean plants without cyanobacteria inoculating within 0-48 hpi (Fig. 3; the dash lines). The maximum levels of this ROS production were obtained at $24 \mathrm{hpi}$ in 20 - and 30-aphid infested leaves, whereas content of $\mathrm{H}_{2} \mathrm{O}_{2}$ in 10-aphid infested variant was continuously increased until $72 \mathrm{hpi}$. Infestation of 30 cowpea aphids per plant caused to release the highest amount of $\mathrm{H}_{2} \mathrm{O}_{2}$, obtaining $16.97 \mathrm{mM} \mathrm{g}^{-1} \mathrm{FW}$, having by 2.36 - and 3.63-fold higher than in control and from beginning, respectively. The most remarkable difference was recorded between content of $\mathrm{H}_{2} \mathrm{O}_{2}$ in aphid-infested and control plants within 6-48 hpi. Similar to $\mathrm{O}_{2}^{-}$, an accumulation of $\mathrm{H}_{2} \mathrm{O}_{2}$ in leaves inoculated with $N$. calcicola HN9 was much lower than that observed in soybean without inoculating cyanobacteria (Fig. 3; the solid lines).

In addition, observations of the relative generation $\mathrm{H}_{2} \mathrm{O}_{2}$ in soybean leaves using confocal microscopy revealed similar trends to the spectrophotometric results. After staining with $2^{\prime}, 7^{\prime}$-dichlorofluorescein diacetate (DCFH-DA) there was observed DCFH-DA-derived fluorescence in soybean leaves. DCFH-DA is a nonpolar dye, converted into the polar derivative DCFH that are non-fluorescent but switched to highly fluorescent DCF when oxidized by intracellular $\mathrm{H}_{2} \mathrm{O}_{2}$. DCF can be 


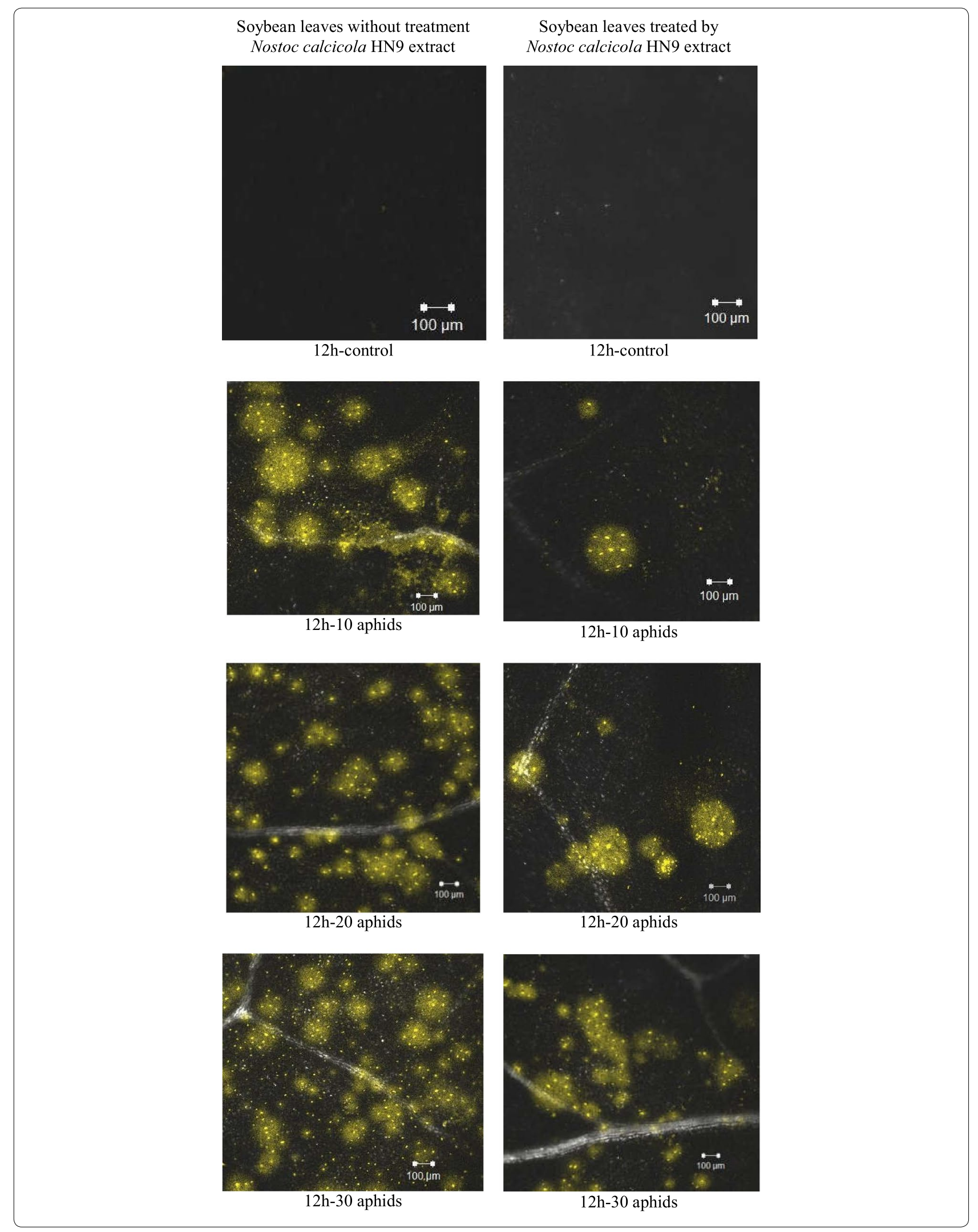


(See figure on previous page.)

Fig. 2 Cytochemical localization of superoxide anion generation $\left(\mathrm{O}_{2}^{-}\right)$in leaves of Glycine max cv. "Nam Dan" under infestation of Aphis craccivora and inoculation of Nostoc calcicola HN9 extract at 12 hpi. Yellow fluorescence came from DHE (dihydroethidium), which is observed by a Zeiss LSM 510 confocal microscope, with excitation at $488 \mathrm{~nm}$, emission at 565-615 nm, objective magnification of 5x, scale bar $100 \mu \mathrm{m}$

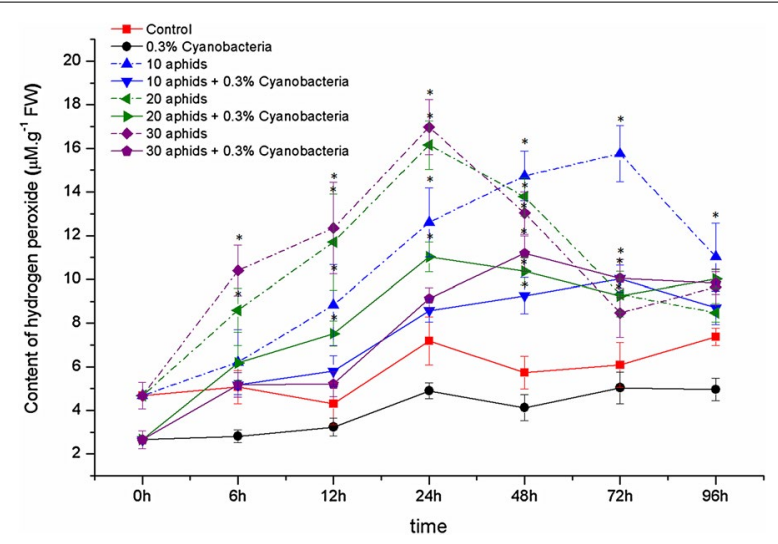

Fig. 3 Generation of hydrogen peroxide $\left(\mathrm{H}_{2} \mathrm{O}_{2}\right)$ in leaves of Glycine max cv. "Nam Dan" under infestation of Aphis craccivora and inoculation of Nostoc calcicola HN9 extract. Values represent means and s.e. from three independent experiments. $\left(^{*}\right)$ In figure shown the significant difference between the experimental variants and control at level $P<0.05$

observed as green color under the fluorescent microscope and intensity of fluorescence is proportional to the endogenous $\mathrm{H}_{2} \mathrm{O}_{2}$ level. A high intensity of fluorescence was observed in the aphid-infested leaves and covered a large uniform area of tissue, whereas no or small trace of fluorescent staining was detected in control (e.g., at $24 \mathrm{hpi}$, Fig. 4). Intensity of green color in N. calcicola HN9-inoculated leaves was remarkably lower in comparing with that recorded in soybean without cyanobacteria treatment.

\section{Cell membrane injury}

The membrane injury degrees in G. $\max$ cells were estimated through assessment of electrolyte leakage and lipid peroxidation.

The electrolyte leakage of soybean leaves' cells was evaluated as the injury percentage compared with control. Without inoculating with $N$. calcicola HN9 extract, the injury percentage in all aphid-infested leaves increased from 0 to $48 \mathrm{hpi}$ and maintained in high levels until 96 hpi (Fig. 5; the dash lines). The highest degree of cellular injury was recorded at $72 \mathrm{hpi}$ in leaves infested by 30 aphids, having $22.45 \%$ higher than in control.

Inoculation of $N$. calcicola HN9 extract seemed to reduce injury rate in the aphid-infested leaves. The injury percentage in soybean inoculated with $N$. calcicola HN9 extract was always significant lower than that observed in plants without treating cyanobacteria. The maximum degree of injury recorded in 30-aphid infested leaves at 96 hpi was only $9.72 \%$ (Fig. 5; the solid lines).

Infestation of A. craccivora induced the lipid peroxidation process in G. max cv. "Nam Dan" leaves (Fig. 6; the dash lines). A small but progressive increase in content of TBARS, the final products of lipid peroxidation, reached the highest level at $96 \mathrm{hpi}$, e.g., 19.87, 21.04 and $23.02 \mathrm{M}$ TBARS $\mathrm{g}^{-1} \mathrm{FW}$ under effect from 10, 20 and 30 aphids, respectively. ANOVA results showed that, content of TBARS in aphid-infested leaves was significantly higher than in control, and an appreciable proportion between levels of TBARS and the infestation intensity of cowpea aphid was exposed since 24 hpi.

Similar to effect on injury percentage of cellular membrane, $N$. calcicola HN9 extract might control lipid peroxidation. This process in plants inoculated with cyanobacteria extract was minor changed during the investigated time; TBARS content was mostly smaller than that observed in soybean without inoculating cyanobacteria (Fig. 6; the solid lines). The maximum content of TBARS obtained in 30-aphid infested/N. calcicola HN9 inoculated leaves at $48 \mathrm{hpi}$ was $17.96 \mathrm{M}^{\text {TBARS g }} \mathrm{g}^{-1}$ FW that was only $78.02 \%$ in comparing with that in 30-aphid infested leaves.

\section{Activity of enzymatic antioxidants}

Analyses of spectrophotometric assays showed that infestation of A. craccivora and inoculation N. calcicola HN9 extract differently induced activity of enzymatic antioxidants such as SOD, CAT and GPx in leaves of G. $\max$ cv. "Nam Dan".

Activity of SOD in soybean leaves infested by different densities of cowpea aphid increased in the first $24 \mathrm{~h}$ of infestation. The highest value of SOD activity recorded in 20 aphid-infested leaves at $24 \mathrm{hpi}$ was $18.08 \mathrm{nkat} \mathrm{mg}^{-1}$ protein, which was 288.9 and $351.3 \%$ higher than SOD activity in control and at the beginning, respectively. After reaching the peak within 24-48 hpi, activity of this enzyme was strongly reduced to low levels but always higher than in control (Fig. 7; the dash lines). ANOVA analyses confirmed the significant differences between the SOD activities in the aphid-infested and control plants during experimental time. However, no appreciable proportion between the infestation intensity and the enhanced activity of SOD was recorded. 


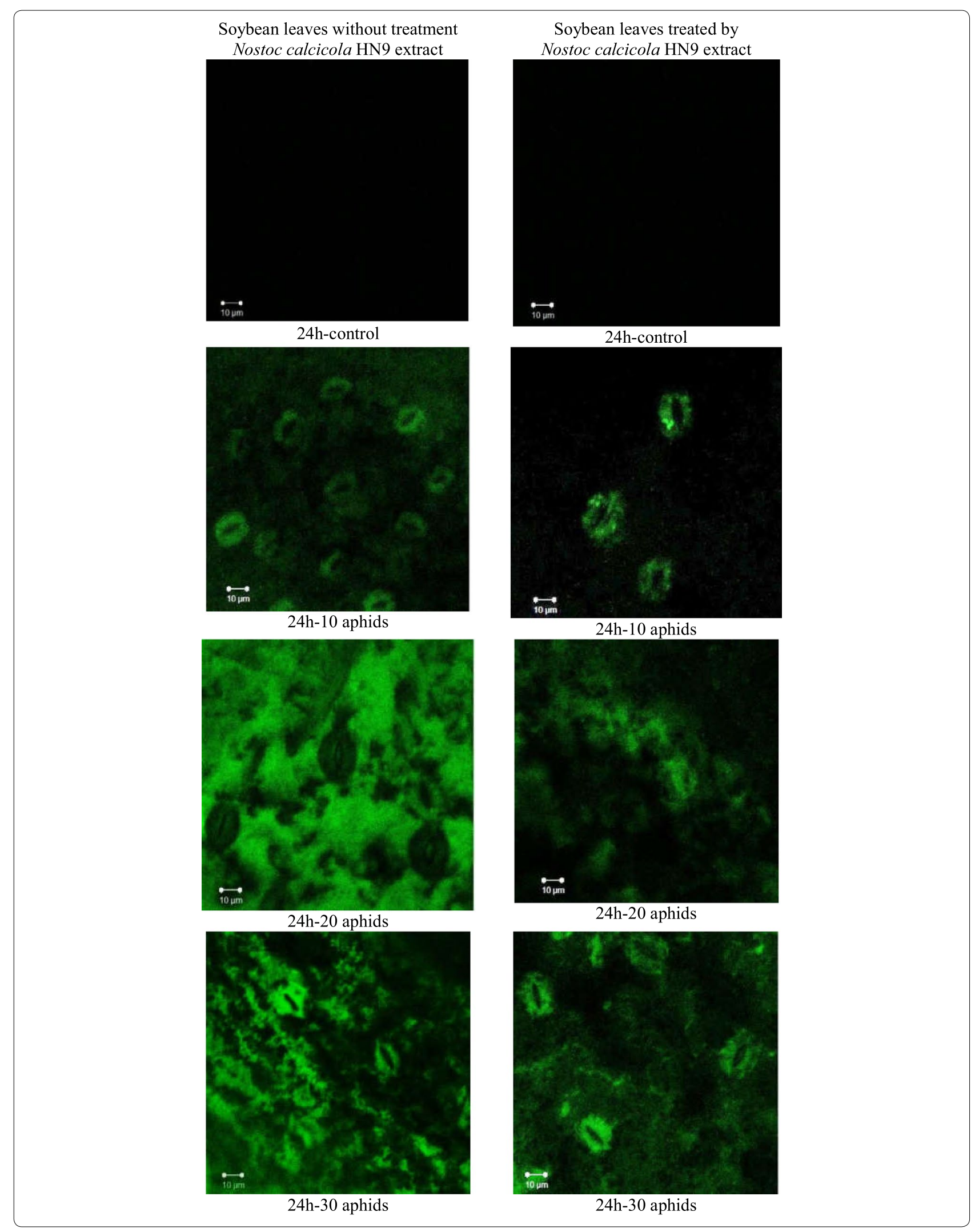


(See figure on previous page.)

Fig. 4 Cytochemical localization of hydrogen peroxide $\left(\mathrm{H}_{2} \mathrm{O}_{2}\right)$ in leaves of Glycine max cv. "Nam Dan" under infestation of Aphis craccivora and inoculation of Nostoc calcicola HN9 extract at $24 \mathrm{hpi}$. Green fluorescence came from DCFH-DA (dichlorodihydro-fluorescein diacetate), which is observed by a Zeiss LSM 510 confocal microscope, with excitation at $488 \mathrm{~nm}$, emission at 500-550 nm, objective magnification of $63 \times$, scale bar $10 \mu \mathrm{m}$

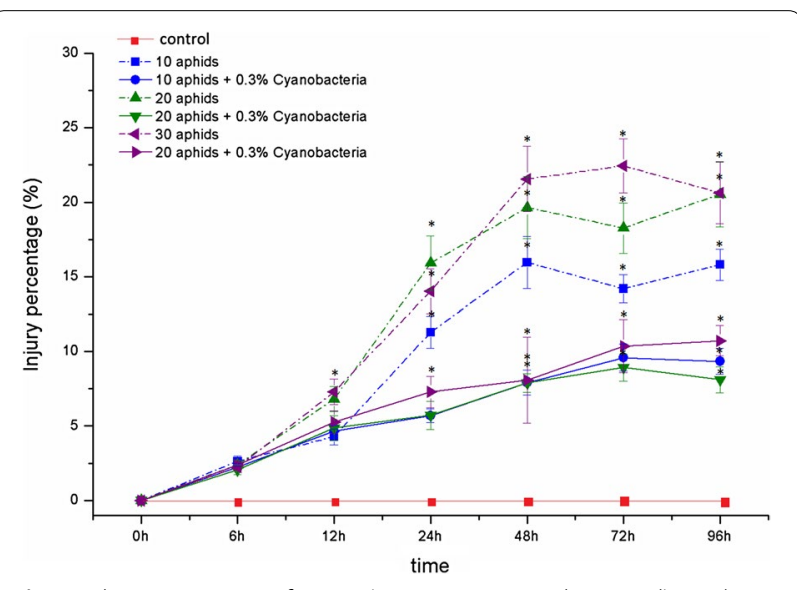

Fig. 5 The percentage of injury (in comparing with control) in Glycine max cv. "Nam Dan" leaves under infestation of Aphis craccivora and inoculation of Nostoc calcicola HN9 extract. Values represent means and s.e. from three independent experiments. ${ }^{*}$ ) In figure shown the significant difference between the experimental variants and control at level $P<0.05$

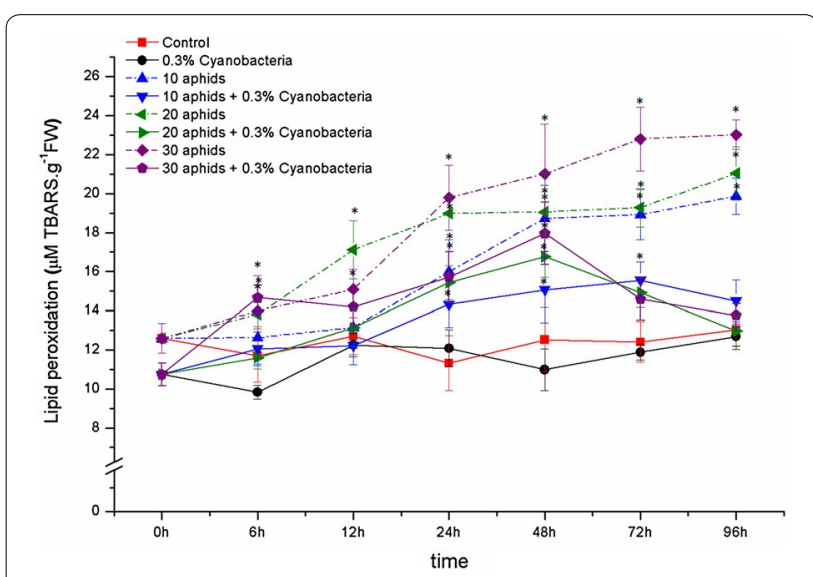

Fig. 6 Lipid peroxidation in leaf tissues of Glycine max cv. "Nam Dan" leaves under infestation of Aphis craccivora and inoculation of Nostoc calcicola HN9 extract. Values represent means and s.e. from three independent experiments. ${ }^{*}$ In figure shown the significant difference between the experimental variants and control at level $\mathrm{P}<0.05$

Inoculation soybean with $N$. calcicola HN9 extract sooner accumulated action of SOD in the aphid-infested leaves. Activity of this enzyme was strongly increased to peak within 12-24 hpi, and maintained in high level up to $96 \mathrm{hpi}$. There was an appreciable proportion between the accumulated activity of SOD and intensity of aphid infestation within 6-72 hpi. The highest activity of SOD enhanced by infestation of 30 aphid individuals at $12 \mathrm{hpi}$ was 20.79 nkat $\mathrm{mg}^{-1}$ protein, having by 2.61 - and 3.32fold higher than that in control and at the beginning, respectively (Fig. 7; the solid lines). ANOVA analyses confirmed that SOD activities in the aphid-infested/ cyanobacteria inoculated soybean leaves were significant higher than that in control plants within 6-96 hpi.

Similar to SOD, enzyme CAT in leaves of soybean "Nam Dan" was also induced after cowpea aphid infestation. An accumulated activity of CAT was observed from the beginning, reached to peak at $48 \mathrm{hpi}$. The highest activity of CAT obtained in 30-aphid infested leaves were 26.54 nkat $\mathrm{mg}^{-1}$ protein, having by $195.49 \%$ higher than in the control (Fig. 8; the dash lines). ANOVA results revealed a significant difference between the activities of CAT in 20- and 30-aphid infested soybean plants and control within 12-72 hpi.

Under effect of N. calcicola HN9 extract, an explosive expression of CAT was observed in aphid-infested leaves. Activity of CAT was remarkably increased and reached to peak within 24-48 hpi. The highest activity of

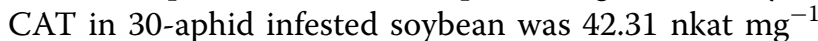
protein at $24 \mathrm{hpi}$, having by 1.59 -folder higher than the maximum activity of CAT in plants without inoculating cyanobacteria (26.54 nkat $\mathrm{mg}^{-1}$ protein). Interestingly, an appreciable proportion between activity of CAT and the infestation intensity of cowpea aphid was also recorded (Fig. 8; the solid lines).

Cowpea aphid infestation also enhanced activity of GPx in leaves of soybean "Nam Dan". Activity of this enzyme was accumulated since $12 \mathrm{hpi}$, increased to maximum at $48 \mathrm{hpi}$, and then slightly reduced to ending of experiments (Fig. 9; the dash lines). The highest activity of GPx obtained in 20 aphid-infested leaves at $48 \mathrm{hpi}$ was 6.91 nkat $\mathrm{mg}^{-1}$ protein, having by 9.24 - and 3.32-fold-higher than that at the beginning and control, respectively.

Inoculating soybean "Nam Dan" by N. calcicola HN9 extract seemed to improve action of GPx in plants infested by cowpea aphid. This antioxidant enzyme in the inoculated leaves was soon induced since $6 \mathrm{hpi}$ and prolonged high activity until 96 hpi. Under effect of $N$. calcicola HN9 extract, the maximum activity of GPx recorded in 30-aphid infested plants at $48 \mathrm{hpi}$ was $12.13 \mathrm{nkat} \mathrm{mg}^{-1}$ protein, having by $175.54 \%$ that observed in soybean without inoculating cyanobacteria. There was a 


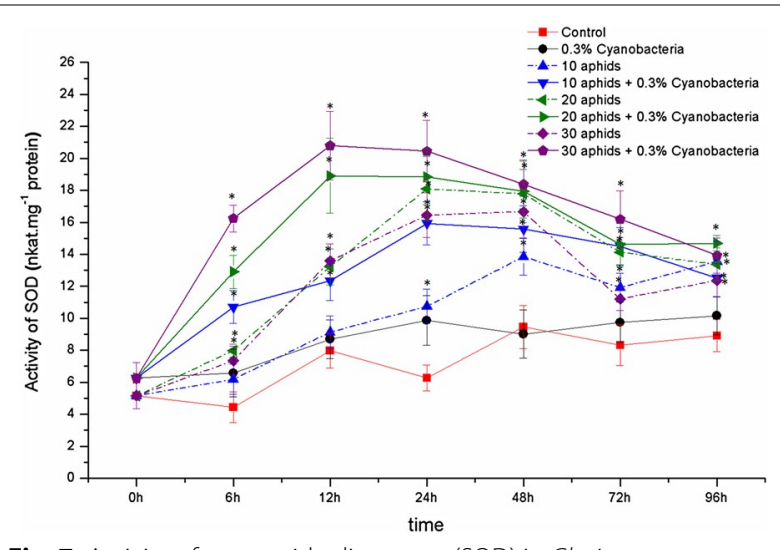

Fig. 7 Activity of superoxide dismutase (SOD) in Glycine max cv. "Nam Dan" leaves under infestation of Aphis craccivora and inoculation of Nostoc calcicola HN9 extract. Values represent means and s.e. from three independent experiments. $\left(^{*}\right)$ In figure shown the significant difference between the experimental variants and control at level $\mathrm{P}<0.05$

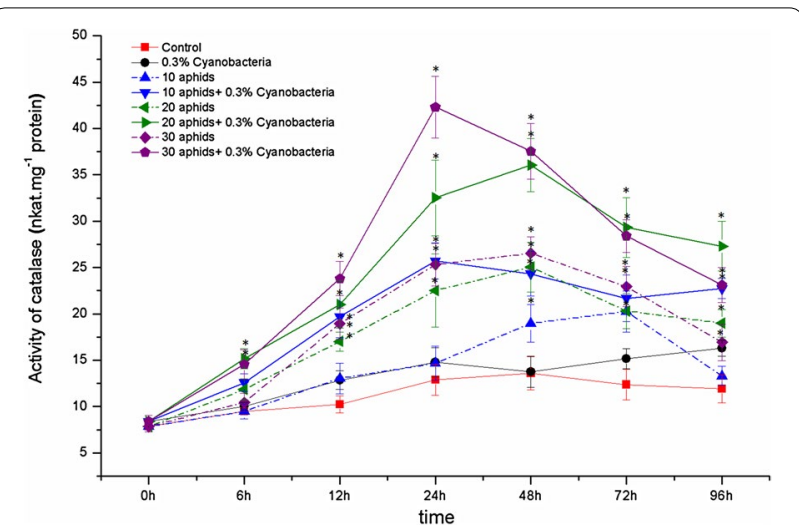

Fig. 8 Activity of catalase (CAT) in Glycine max cv. "Nam Dan" leaves under infestation of Aphis craccivora and inoculation of Nostoc calcicola HN9 extract. Values represent means and s.e. from three independent experiments. $\left(^{*}\right.$ ) In figure shown the significant difference between the experimental variants and control at level $P<0.05$

significant difference between activity of GPx in the aphid-infested plants and control since $6 \mathrm{hpi}$, however, the relationship between the accumulated enzymatic activity and intensity of infestation was unappreciable (Fig. 9; the solid lines).

\section{Discussion}

Feeding of insects, including aphids, has been known to induce generation of the endogenous $\mathrm{ROS}$ such as $\mathrm{O}_{2}^{--}$ and $\mathrm{H}_{2} \mathrm{O}_{2}$ in plants (Orozco-Cárdenas and Ryan 1999; $\mathrm{Ni}$ et al. 2001; Argandona et al. 2001; Zhu-Salzman et al. 2004; Moloi and van der Westhuizen 2006; Ślesak et al. 2007; Kuśnierczyk et al. 2008; Rangasamy et al. 2009;
Liu et al. 2010; Radville et al. 2011; Morkunas et al. 2011; Mai et al. 2013, 2016). Similar to previous studies, infestation of $A$. craccivora accumulated a strong release of $\mathrm{O}_{2}^{--}$and $\mathrm{H}_{2} \mathrm{O}_{2}$ in leaves of G. $\max$ cv. "Nam Dan" (Figs. 1, 3 ). The induced generation of $\mathrm{O}_{2}^{--}$constitutes an important aspect of plant potential defense (Mai et al. 2013). Induction of $\mathrm{O}_{2}^{--}$within a short time after stress mediated rapid local resistance mechanisms in plants against insect larvae, leading to cell death (Bown et al. 2002), might play an important function in protection against infection by opportunistic pathogens at the site of the larval footprint damage (Hall et al. 2004). A large amount of $\mathrm{O}_{2}^{--}$in cell wall may limit the pathogen invasion that can be directly transmitted from aphid saliva during its penetration into plant tissues (Capinera 2001). Different from $\mathrm{O}_{2}^{--}$functions, enhancement of $\mathrm{H}_{2} \mathrm{O}_{2}$ stimulates a cascade of many physiological and molecular responses (Maffei et al. 2007). $\mathrm{H}_{2} \mathrm{O}_{2}$ causes to release of $\mathrm{Ca}^{2+}$ flux into the cellular matrix, which is the control point for signal transduction processes or activates some members of the mitogen-activated protein kinase (MAPK) familycentral for mediating cellular responses to stresses (Neill et al. 2002). $\mathrm{H}_{2} \mathrm{O}_{2}$ can tighten the cell wall by driving lignification as well as enabling the oxidative coupling of polysaccharide-bound phenolics, which strengthen barriers to aphid probing within plant tissues (Vreeburg and Fry 2005; Gapper and Dolan 2006), leading to prevent or minimize aphid attack (Argandona et al. 2001), reflecting a defensive role on protection plant tissues from wounding.

However, high levels of ROS can exert toxic effects and caused "oxidative stress" to plant cells. The uncontrolled productions of ROS can result in damages of cellular components such as proteins, lipids, and nucleic acids (Ahmad et al. 2008), often associated cell membrane injury leading to electrolyte leakage and lipid peroxidation. As aphid probing into plant tissues, components of sheath and watery saliva may establish the physical and chemical properties to cause the extensive cellular disruption. An increased electrolyte leakage is used to indicate loss of membrane integrity, and soybean cells membranes may be subject to changes under cowpea aphid infestation. Lipid peroxidation involves the formation of lipid radicals, the eventual destruction of membrane lipids, is also considered as the oxidative damage to cell structures that may lead to cell death (Dianzani and Barrera 2008). Under effects from different densities of $A$. craccivora, an extension of electrolyte leakage and a progressive increase in content of TBARS-the final products of lipid peroxidation were observed in leaves of G. $\max$ cv. "Nam Dan" (Figs. 5, 6; the dash lines). That was certain symptoms of cellular damage resulting from oxidative stress caused by cowpea aphid infestation. 


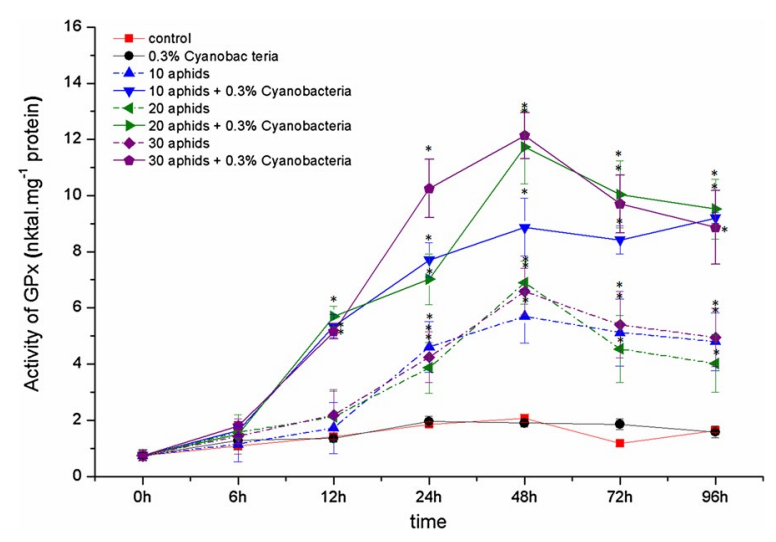

Fig. 9 Activity of glutathione peroxidase (GPx) in Glycine max cv. "Nam Dan" leaves under infestation of Aphis craccivora and inoculation of Nostoc calcicola HN9 extract. Values represent means and s.e. from three independent experiments. $\left(^{*}\right)$ In figure shown the significant difference between the experimental variants and control at level $P<0.05$

Regarding effects of inoculation cyanobacteria to crops, several previous reports showed that cyanobacterial materials could induce productions of oxidants. Nostoc sp. extract caused a burst of $\mathrm{O}_{2}^{--}$and $\mathrm{H}_{2} \mathrm{O}_{2}$ generation leading to the cellular damages in root of Mimosa pigra (Sukkhaeng et al. 2015). Lipid peroxidation in M. pigra and Vallisneria natans plants also significantly increased after treatment of cyanobacterial extract (Jiang et al. 2011; Sukkhaeng et al. 2015). The cyanobacterial bloom products caused an oxidative damage in Medicago sativa seedlings (Pflugmacher et al. 2006). Furthermore, some bioactive substances from cyanobacteria extract can be toxic to plant tissues, even result in cell death. For example, Nostocine A produced by N. spongiaeforme TISTR 8169 exhibited an inhibitory activity on root growth of barnyard grass (Hirata et al. 2003). Microcystin-RR from Microcystis aeruginosa decreased cell viability of tobacco after inoculation (Yin et al. 2005). Different from the above results, Nostoc species have several antioxidant properties, due to their ability to scavenge free radicals such as $\mathrm{O}_{2}^{--}$and $\mathrm{OH}^{-}$and inhibit lipid peroxidation ( $\mathrm{Li}$ et al. 2007). In this light, our study also revealed that, inoculation of $N$. calcicola HN9 extract depressed generation of $\mathrm{O}_{2}^{--}$and $\mathrm{H}_{2} \mathrm{O}_{2}$; levels of those ROS remarkably decreased in leaves of G. max cv. "Nam Dan" infested by A. craccivora. Extract of this cyanobacterium strain may exhibit potential adaptation strategies against oxidative stress in soybean "Nam Dan". The extract could activate plant antioxidant defense system that comprises various enzymatic antioxidants that mainly caused a reduction of ROS content (Bharanidharan et al. 2013; Guedes et al. 2013). Moreover, cyanobacteria extract also contains phenolic acids, flavonoids and other non-enzymatic antioxidants that improve plant adaptive responses to oxidative stress (Honga et al. 2008; Krishnaraj et al. 2012). Phenolic acids and flavonoids are able to donate hydrogen atom to the free radical thus stopping the propagation chain reaction during lipid peroxidation process (Abd El-Baky et al. 2009). It is known that prevention of the chain initiation step by scavenging ROS products is considered to be an important mode of antioxidative mechanism (Ruberto et al. 2001). Moreover, most phenolic compounds found in the cyanobacteria extract contained the protonated form with the high chelating ability (Goh et al. 2010). The ability to chelate off the ferrous ion is important to avoid a Fenton reaction, which would produce the harmful free radicals such as $\mathrm{O}_{2}^{-}$. The presence of phenolic acids and flavonoids were supposed to impart prominent antioxidant properties that detoxify ROS products (Perron and Brumaghim 2009; Reuter et al. 2010; Singh et al. 2017).

Parallel action of non-enzymatic antioxidants, plant cells can scavenge toxicity of ROS products via enzymes such as superoxide dismutase (SOD), catalase (CAT), and other enzymatic antioxidants (Maffei et al. 2007; Ahmad et al. 2008). Potential roles of SOD and CAT in signaling and control of ROS production have been implicated in plant defense response to insect herbivores, including aphids (Ni et al. 2001; Gomez et al. 2004; Heng-Moss et al. 2004; Wei et al. 2007; Moloi and van der Westhuizen 2008; Rangasamy et al. 2009; Ferry et al. 2011; Mai et al. 2013). In agreement with the above results, our study revealed that the accumulated activity of SOD and CAT under infestation of $A$. craccivora is an aspect of antioxidative responses of G. max cv. "Nam Dan" to cowpea aphid. Within living cells, SOD constitutes the first line of defense against ROS (Alscher et al. 2002), because this enzyme can counteract oxidative damage caused by regulating levels of $\mathrm{O}_{2}^{-}$(Abassi et al. 1998). The strong accumulated activity of CAT protects the plant cells against an excess of $\mathrm{H}_{2} \mathrm{O}_{2}$ and thus against considerable membrane damage (Rani and Jyothsna 2010). The potential defensive roles of SOD, CAT to control of ROS products have been involved in plant resistance to aphids (Rangasamy et al. 2009; Ferry et al. 2011).

Up to date, limited information has been mentioned about effects of cyanobacteria species on expression of the enzymatic antioxidants in plant defense mechanism. Inoculation cyanobacterial crude extract on alfalfa enhanced activities of SOD, CAT and other enzymes in response of alfalfa to oxidative stress (Pflugmacher et al. 2006). CAT activity significantly increased in $M$. pigra plant since $24 \mathrm{~h}$ after treating by Nostoc sp. extract (Sukkhaeng et al. 2015). Extract of N. commune, Anabaena flos-acquae and Westiellopsis sp. was found to enhance 
activity of CAT and POX of medicinal plant flax (Naresh et al. 2013). In soybean-cowpea aphid interaction, inoculation the aphid-infested leaves with $N$. calcicola HN9 extract improved activity of SOD and CAT (Figs. 7, $8)$. Because most cyanobacterial species contain a wide range of enzymes such as SOD, CAT, and other enzymatic antioxidants (Bharanidharan et al. 2013; Guedes et al. 2013; Gunes et al. 2015; Ghalab et al. 2016), SOD and CAT from N. calcicola HN9 extract probably augmented to the antioxidant defense system of soybean. The accumulated activity of SOD and CAT in soybean defense mechanism might be resulted from the acted combination or resonance of those enzymes originated from both soybean plant and cyanobacteria extract. The presence of high activity of enzymatic antioxidants in cyanobacteria extract may also be considered as a part of the key functions which contribute to protect of plants from effect of unfavorable factors, including aphids (Aydas et al. 2013; Singh et al. 2014).

Another important enzyme in $\mathrm{H}_{2} \mathrm{O}_{2}$-scavenging is $\mathrm{GPx}$ from the non-heme containing peroxidase family (Bela et al. 2015). Different from SOD and CAT, GPx was not detected in cyanobacteria (Tel-Or et al. 1986); therefore, the accumulated activity of this enzyme recorded in our study was originated only from soybean plant. An accumulation of GPx was as an aspect of soybean defense mechanism. GPx can regulate diverse defensive signaling pathways during oxidative stress and other unfavorable factors (Milla et al. 2003; Navrot et al. 2006; Diao et al. 2014; Gao et al. 2014). Typically, GPx is part of an alternative pathway that scavenges peroxides such as $\mathrm{H}_{2} \mathrm{O}_{2}$, phospholipid hydroperoxides, thereby protects cell membranes from peroxidative damage (Gueta-Dahan et al. 1997). It should be stressed that, inoculation of N. calcicola HN9 extract strongly improved activity of GPx in soybean leaves during cowpea aphid attack. This enzyme was accumulated since $6 \mathrm{hpi}$, reached to maximum activity at $48 \mathrm{hpi}$ and maintained in high level up to ending of experiment; GPx activity was always significantly higher than that in soybean without inoculating cyanobacteria extract (Fig. 9).

Taken together, the aforementioned results provided the persuasive evidence that components of $N$. calcicola HN9 extract may strengthen the defensive capability of G. max cv. "Nam Dan" to cowpea aphid infestation via establishing the chemical constraints on oxidative stress. Cyanobacteria extract probably not only directly controlled the generation of $\mathrm{O}_{2}^{--}$and $\mathrm{H}_{2} \mathrm{O}_{2}$ but also developed a range of chemical properties to limit aphid feeding. Furthermore, $N$. calcicola HN9 extract might augment activity of SOD and CAT, enhance action of GPx, allowed those enzymatic antioxidants to play crucial functions in defense mechanism of soybean "Nam Dan" to strictly reduce the toxic effects of ROS products.
Additionally, a high generation of $\mathrm{O}_{2}^{--}$and $\mathrm{H}_{2} \mathrm{O}_{2}$, an accumulated activity of enzymatic antioxidants, and low cellular damages in leaves of G. max cv. "Nam Dan" after A. craccivora infestation suggest that it may be a aphid resistant variety of soybean.

In conclusion, the enzymatic antioxidants such as SOD, CAT and GPx are important elements of soybean defense responses against cowpea aphid infestation. The accumulation of those enzymes can be thought of a reflection of intrinsic strategies to reduce damages caused due to ROS generated during aphid attack. Inoculation soybean plant with $N$. calcicola HN9 extract, which contains various enzymatic and non-enzymatic antioxidants, strengthened the adaptive potential to protect soybean from oxidative stress, contributed to increase the resistance of G. $\max$ cv. "Nam Dan" to A. craccivora. The improved antioxidative responses of G. max cv. "Nam Dan" to A. craccivora infestation under effect of $N$. calcicola HN9 extract can be a novel aspect of bio-protection, which is an integral component of the friendly strategies for sustainable agriculture.

\begin{abstract}
Abbreviations
CAT: catalase; FW: fresh weight; GPx: glutathione peroxidase; $\mathrm{H}_{2} \mathrm{O}_{2}$ : hydrogen peroxide; hpi: hours post infestation; nkat: nanokatal; $\mathrm{O}_{2}^{--}$: superoxide anion radical; SOD: superoxide dismutase.
\end{abstract}

\section{Authors' contributions}

LAVN was responsible for cyanobacteria culture. DDN supplied all laboratory and chemical substances used in this study. VCM and BHN designed the experiment. VCM and LAVN determined, analyzed the data, and drafted the manuscript. All authors read and approved the final manuscript.

\section{Author details}

${ }^{1}$ Department of Plant Physiology, School of Natural Sciences Education, Vinh University, str. Le Duan 182, Vinh, Nghe An Province, Vietnam. ${ }^{2}$ Department of Environmental Sciences, School of Chemo-Biology and Environment Technology, Vinh University, str. Le Duan 182, Vinh, Nghe An Province, Vietnam.

\section{Acknowledgements}

We are thankful to Vietnam National Foundation for Science and Technology Development (NAFOSTED) under Grant Number: 106-NN.03-2014.2 for financial support.

\section{Competing interests}

The authors declare that they have no competing interests.

\section{Availability of data and materials}

This study is a part of our project that belongs to Vietnam National Foundation for Science and Technology Development. Our project has not been ended yet; therefore, data will not be shared until we complete all project works.

\section{Consent for publication}

Not applicable.

\section{Ethics approval and consent to participate}

Manuscripts reporting studies involving human participants, human data or human tissue must: a statement on ethics approval and consent: not applicable. the name of the ethics committee: not applicable.

\section{Funding}

This research is funded by Vietnam National Foundation for Science and Technology Development (NAFOSTED) under Grant Number: 106-NN.03-2014.2. 


\section{Publisher's Note}

Springer Nature remains neutral with regard to jurisdictional claims in published maps and institutional affiliations.

Received: 26 May 2017 Accepted: 23 November 2017 Published online: 28 November 2017

\section{References}

Abassi NA, Kushad MM, Endress AG (1998) Active oxygen-scavenging enzymes activities in developing apple flowers and fruits. Sci HorticAmst 74:183-194

Abd El-Baky HH, El-Baz FK, El-Barot GS (2009) Production of phenolic compounds from Spirulina maxima microalgae and its protective effects. Afr J Biotechnol 8:7059-7067

Ahmad P, Sarwat M, Sharma S (2008) Reactive oxygen species, antioxidants and signaling in plants. J Plant Biol 51:167-173

Alscher RG, Erturkm N, Heathm LS (2002) Role of superoxide dismutases (SODs) in controlling oxidative stress in plants. J Exp Bot 53:1331-1341

Argandona VH, Chaman M, Cardemil L, Munoz O, Zuniga GE, Corcuera LJ (2001) Ethylene production and peroxidase activity in aphid-infested barley. J Chem Ecol 27:53-68

Aydas SB, Ozturk S, Aslim B (2013) Phenylalanine ammonia lyase (PAL) enzyme activity and antioxidant properties of some cyanobacteria isolates. Food Chem 136:164-169

Bajji M, Kinet J-M, Lutts S (2002) The use of the electrolyte leakage method for assessing cell membrane stability as a water stress tolerance test in durum wheat. Plant Growth Regul 36(1):61-70

Beauchamp C, Fridovich I (1971) Superoxide dismutase: improved assays and an assay applicable to acrylamide gels. Anal Biochem 44:276-287

Becana M, Aparicio-Tejo P, Irigoyen JJ, Sanchez-Diaz M (1986) Some enzymes of hydrogen peroxide metabolism in leaves and root nodules of Medicago sativa. Plant Physiol 82:1169-1171

Bela K, Horváth E, Gallé Á, Szabados L, Tari I, Csiszár J (2015) Plant glutathione peroxidases: emerging role of the antioxidant enzymes in plant development and stress responses. J Plant Physiol 176:192-201

Bharanidharan M, Sivasubramanian V, Raja SR, Nayagam V (2013) Evaluation of antioxidant and antimicrobial potential of cyanobacteria, Chroococcus turgidus (Kützing) Nägeli. Int J Curr Microbiol App Sci 2:300-305

Bown AW, Hall DE, MacGregor KB (2002) Insect footsteps on leaves stimulate the accumulation of 4-aminobutyrate and can be visualized through increased chlorophyll fluorescence and superoxide production. Plant Physiol 129:1430-1434

Bradford M (1976) A rapid and sensitive method for quantitation of microgram quantities of protein utilizing the principle of protein-dye binding. Anal Biochem 72:248-254

Capinera JL (2001) Handbook of vegetable pests. Academic Press, New York

Dhindsa RS, Plumb-Dhindsa P, Thorpe TA (1981) Leaf senescence: correlated with increased levels of membrane permeability and lipid peroxidation, and decrease levels of superoxide dismutase and catalase. J Exp Bot 32:93-101

Dianzani M, Barrera G (2008) Pathology and physiology of lipid peroxidation and its carbonyl products. In: Álvarez S, Evelson P (eds) Free radical pathophysiology. Transworld Research Network, Thiruvananthapuram, pp 19-38

Diao Y, Xu H, Li G, Yu A, Yu X, Hu W et al (2014) Cloning a glutathione peroxidase gene from Nelumbo nucifera and enhanced salt tolerance by overexpressing in rice. Mol Biol Rep 41:4919-4927

Doke N (1983) Involvement of superoxide anion generation in the hypersensitive response of potato tuber tissues to infection with an incompatible race of Phytophthora infestans and to the hyphal wall components. Physiol Mol Plant Pathol 23:345-355

Ferry N, Stavroulakis S, Guan W, Davison GM, Bell HA, Weaver RJ, Down RE, Gatehouse JA, Gatehouse AMR (2011) Molecular interactions between wheat and cereal aphid (Sitobion avenae): analysis of changes to the wheat proteome. Proteomics 11:1985-2002

Flohé L, Günzler WA (1984) Assays of glutathione peroxidase. Methods Enzymol 105:114-121
Gao F, Chen J, Ma T, Li H, Wang N, Li Z et al (2014) The glutathione peroxidase gene family in Thellungiella salsuginea: genome-wide identification, classification, and gene and protein expression analysis under stress conditions. Int J Mol Sci 15:3319-3335

Gapper C, Dolan L (2006) Control of plant development by reactive oxygen species. Plant Physiol 141:341-345

Ghalab NM, Tantawy EA, Khalil HMA, Shaban KA (2016) Plant growth promoters substances that excreting from bacteria and cyanobacteria as essential factors for alleviation soil salt stress on rice plant. J Microbiol Res 6(5):103-110

Goh S, Yusoff FM, Loh SP (2010) A comparison of the antioxidant properties and total phenolic content in a diatom, Chaetoceros sp. and a green microalga, Nannochloropsis sp. J Agric Sci 2:123-130

Gomez SK, Oosterhuis D, Rajguru SN, Johnson DR (2004) Foliar antioxidant enzyme responses in cotton after aphid herbivory. J Cotton Sci 8:99-104

Guedes AC, Gião MS, Seabra R, Ferreira AC, Tamagnini P, MoradasFerreira P, Malcata FX (2013) Evaluation of the antioxidant activity of cell extracts from microalgae. Mar Drugs 11:1256-1270

Gueta-Dahan Y, Yaniv Z, Zilinskas BA, Ben-Hayyim G (1997) Salt and oxidative stress: similar and specific responses and their relation to salt tolerance in Citrus. Planta 203:460-469

Gunes S, Tamburaci S, Imamoglu E, Dalay MC (2015) Determination of superoxide dismutase activities in different cyanobacteria for scavenging of reactive oxygen species. J Biol Act Prod Nat 5(1):25-32

Hall DE, MacGregor KB, Nijsse J, Bown AW (2004) Footsteps from insect larvae damage leaf surfaces and initiate rapid responses. Eur J Plant Pathol 110:441-447

Heath RL, Packer L (1968) Photoperoxidation in isolated chloroplasts. I. Kinetics and stoichiometry of fatty acid peroxidation. Arch Biochem Biophys 125:189-198

Heng-Moss T, Sarath G, Baxendale F, Novak N, Bose S, Ni X, Quisenberry S (2004) Characterization of oxidative enzyme changes in buffalograsses challenged by Blissus occiduus. J Econ Entomol 97:1086-1095

Hirata K, Yoshitomi S, Dwi S, Iwabe O, Mahakhant A, Plochai J, Miyamoto K (2003) Bioactivities of Nostocine-a produced by a freshwater cyanobacterium Nostoc spongiaeforme TISTR 8169. J Biosci Bioeng 95:512-517

Honga Y, Hua HY, Xiea X, Li FM (2008) Responses of enzymatic antioxidants and non-enzymatic antioxidants in the cyanobacterium Microcystis aeruginosa to the allelochemical ethyl 2-methyl acetoacetate (EMA) isolated from reed (Phragmites communis). J Plant Physiol 165:1264-1273

Jäger K, Bartók T, Ördög V, Barnabás B (2010) Improvement of maize (Zea mays L.) anther culture responses by algae-derived natural substances. S Afr J Bot 76:511-516

Jiang J, Gu X, Song R, Wang X, Yang L (2011) Microcystin-LR induced oxidative stress and ultrastructural alterations in mesophyll cells of submerged macrophyte Vallisneria natans (Lour.) Hara. J Hazard Mater 190:188-196

Khattab H (2007) The defense mechanism of cabbage plant against phloemsucking aphid (Brevicoryne brassicae L.). Aust J Basic Appl Sci 1:56-62

Komárek J (2010) Modern taxonomic revision of planktic nostocacean cyanobacteria: a short review of genera. Hydrobiologia 639:231-243

Krishnaraj RN, Babu SV, Ashokkumar B, Malliga P, Varalakshmi P (2012) Antioxidant property of fresh and marine water cyanobacterial extracts in Swiss mice. J Biopestic 5:250-254

Kulik MM (1995) The potential for using cyanobacteria (blue-green algae) and algae in the biological control of plant pathogenic bacteria and fungi. Eur J Plant Pathol 101(6):585-599

Kuśnierczyk A, Winge P, Jørstad TM, Troczyńska J, Rossiter JT, Bones AM (2008) Towards global understanding of plant defense against aphids-timing and dynamics of early Arabidopsis defense responses to cabbage aphid (Brevicoryne brassicae) attack. Plant Cell Environ 31:1097-1115

Li AH, Cheng K, Wong C, King-Wai F, Feng C, Yue J (2007) Evaluation of antioxidant capacity and total phenolic content of different fractions of selected microalgae. Food Chem 102:771-776

Liu X, Williams CE, Nemacheck JA, Wang H, Subramanyam S, Zheng C, Chen MS (2010) Reactive oxygen species are involved in plant defense against a gall midge. Plant Physiol 152:985-999

Maffei ME, Mithöfer A, Boland W (2007) Insects feeding on plants: rapid signals and responses preceding the induction of phytochemical release. Phytochemistry 68:2946-2959 
Mai VC, Bednarski W, Borowiak-Sobkowiak B, Wilkaniec B, Samardakiewicz S, Morkunas I (2013) Oxidative stress in pea seedling leaves responses to Acyrthosiphon pisum infestation. Phytochemistry 93:49-62

Mai VC, Tran NT, Nguyen DS (2016) The involvement of peroxidases in soybean seedlings' defense against infestation of cowpea aphid. ArthropodPlant Interact 10(4):283-292

Małecka A, Piechalak A, Tomaszewska B (2009) Reactive oxygen species production and antioxidative defense system in pea root tissues treated with lead ions: the whole roots level. Acta Physiol Plant 31:1053-1063

Milla MAR, Maure A, Huete AR, Gustafson JP (2003) Glutathione peroxidase genes in Arabidopsis are ubiquitous and regulated by abiotic stresses through diverse signaling pathways. Plant J 36:602-615

Moloi MJ, van der Westhuizen AJ (2006) The reactive oxygen species are involved in resistance responses of wheat to the Russian wheat aphid. J Plant Physiol 163:1118-1125

Moloi MJ, van der Westhuizen AJ (2008) Antioxidative enzymes and the Russian wheat aphid (Diuraphis noxia) resistance response in wheat (Triticum aestivum). Plant Biol 10:403-407

Morkunas I, Bednarski W (2008) Fusarium oxysporum-induced oxidative stress and antioxidative defenses of yellow lupine embryo axes with different sugar levels. J Plant Physiol 165:262-277

Morkunas I, Mai VC, Gabrys B (2011) Phytohormonal signaling in plant responses to aphid feeding. Acta Physiol Plant 33:2057-2073

Naresh L, Alex BK, Koshy EP (2013) Effect of different cyanobacterial species on growth, photosynthetic activity and antioxidant system of flax plant. Int J Pharm Bio Sci 4(4):(B) 446-(B) 455

Navrot N, Collin V, Gualberto J, Gelhaye E, Hirasawa M, Rey P, Knaff DB, Issakidis E, Jacquot JP, Rouhier N (2006) Plant glutathione peroxidases are functional peroxiredoxins distributed in several subcellular compartments and regulated during biotic and abiotic stresses. Plant Physiol 142:1364-1379

Neill SJ, Desikan R, Clarke A, Hurst RD, Hancock JT (2002) Hydrogen peroxide and nitric oxide as signalling molecules in plants. J Exp Bot 53:1237-1247

Ni X, Quisenberry SS, Heng-Moss T, Markwell JP, Sarath G, Klucas R, Baxendale FP (2001) Oxidative responses of resistant and susceptible cereal leaves to symptomatic and nonsymptomatic cereal aphid (Hemiptera: Aphididae) feeding. J Econ Entomol 94:743-751

Nowruzi B, Khavari-Nejad R-A, Sivonen K, Kazemi B, Najafi F, Nejadsattari $T$ (2012) Identification and toxigenic potential of a Nostoc sp. Algae 27:303-313

Orozco-Cárdenas M, Ryan CA (1999) Hydrogen peroxide is generated systemically in plant leaves by wounding and systemin via the octadecanoid pathway. PNAS USA 96:6553-6557

Perron NR, Brumaghim JL (2009) A review of the antioxidant mechanisms of polyphenol compounds related to iron binding. Cell Biochem Biophys 53:75-100

Pflugmacher S, Jung K, Lundvall L, Neumann S, Peuthert A (2006) Effects of cyanobacterial toxins and cyanobacterial cell-free crude extract on germination of alfalfa (Medicago sativa) and induction of oxidative stress. Environ Toxicol Chem 25(9):2381-2387

Prasanna R, Chaudhary V, Gupta V, Babu S, Kumar A, Singh R, Shivay YS, Nain L (2013) Cyanobacteria mediated plant growth promotion and bioprotection against Fusarium wilt in tomato. Eur J Plant Pathol 136:337-353

Radville L, Chaves A, Preisser EL (2011) Variation in plant defense against invasive herbivores: evidence for a hypersensitive response in Eastern Hemlocks (Tsuga canadensis). J Chem Ecol 37:592-597

Rana A, Joshi M, Prasanna R, Shivay YS, Nain L (2012) Biofortification of wheat through inoculation of plant growth promoting rhizobacteria and cyanobacteria. Eur J Soil Biol 50:118-126

Rangasamy M, Rathinasabapathi B, McAuslane HJ, Cherry RH, Nagata RT (2009) Oxidative responses of St. Augustinegrasses to feeding of southern chinch bug, Blissus insularis Barber. J Chem Ecol 35:796-805

Rani PU, Jyothsna Y (2010) Biochemical and enzymatic changes in rice plants as a mechanism of defense. Acta Physiol Plant 32:695-701

Reuter S, Gupta SC, Chaturvedi MM, Aggarwal BB (2010) Oxidative stress, inflammation and cancer: how are they linked? Free Radic Biol Med 49:1603-1616

Rippka R, Deruelles J, Waterbury JB, Herdman M, Stanier RY (1979) Generic assignments, strain histories and properties of pure cultures of cyanobacteria. J Gen Microbiol 111:1-61
Ruberto G, Baratta MT, Biondi DM, Amico V (2001) Antioxidant activity of extracts of the marine algal genus Cystoseira in a micellar model system. J Appl Physiol 13:403-407

Saadatnia H, Riahi H (2009) Cyanobacteria from paddy fields in Iran as a biofertilizer in rice plants. Plant Soil Environ 55:207-212

Shariatmadari Z, Riahi H, Shokravi S (2011) Study of soil blue-green algae and their effect on seed germination and plant growth of vegetable crops. Rostaniha 12:101-110

Shariatmadari Z, Riahi H, Hashtroudi MS, Ghassempour AR, Aghashariatmadary Z (2013) Plant growth promoting cyanobacteria and theirdistribution in terrestrial habitats of Iran. Soil Sci Plant Nutr 59(4):535-547

Sharma P, Jha AB, Dubey RS, Pessarakli M (2012) Reactive oxygen species, oxidative damage, and antioxidative defense mechanism in plants under stressful conditions. J Bot 2012:26. https://doi.org/10.1155/2012/217037

Singh DP, Prabha R, Meena KK, Sharma L, Sharma AK (2014) Induced accumulation of polyphenolics and flavonoids in cyanobacteria under salt stress protects organisms through enhanced antioxidant activity. Am J Plant Sci 5:726-735

Singh DP, Prabha R, Verma S, Meena KK, Yandigeri M (2017) Antioxidant properties and polyphenolic content in terrestrial cyanobacteria. Biotech 7:134. https://doi.org/10.1007/s13205-017-0786-6

Ślesak I, Libik M, Karpinska B, Karpinski S, Miszalski Z (2007) The role of hydrogen peroxide in regulation of plant metabolism and cellular signalling in response to environmental stresses. Acta Biochim Pol 54:39-50

Smith CM, Boyko EV (2007) The molecular bases of plant resistance and defense responses to aphid feeding: current status. Entomol Exp Appl 122:1-16

Sukkhaeng S, Sanevas N, Suwanwong S (2015) Nostoc sp. extract induces oxidative stress mediated root cell destruction in Mimosa pigra L. Bot Stud 56:3. https://doi.org/10.1186/s40529-014-0081-3

Tel-Or E, Huflejt ME, Packer L (1986) Hydroperoxide metabolism in cyanobacteria. Arch Biochem Biophys 246(1):396-402

Tran VH, Nguyen DD, Nguyen LAV, Mai VC (2016) Effect of Nostoc calcicola extract on soybean "Nam Dan" in the vegetative stages. In: Proceeding of Vietnam national conference of research on biology, Da Nang, 20 May 2016; pp 1044-1051 (In Vietnamese)

Vreeburg RAM, Fry SC (2005) Reactive oxygen species in cell walls. In: Smirnoff $\mathrm{N}$ (ed) Antioxidants and reactive oxygen species in plants. Blackwell Publishing Ltd., Oxford, pp 215-249

Wei H, Zhikuan J, Qingfang H (2007) Effects of herbivore stress by Aphis medicaginis Koch on the malondialdehyde contents and the activities of protective enzymes in different alfalfa varieties. Acta Ecol Sin 27(6):2177-2183

Yin L, Huang J, Huang W, Li D, Wang G, Liu Y (2005) Microcystin-RR-induced accumulation of reactive oxygen species and alteration of antioxidant systems in tobacco BY-2 cells. Toxicon 46:507-512

Zhu-Salzman K, Salmon RA, Ahn JE, Koiwa H (2004) Transcriptional regulation of sorghum defense determinants against a phloem-feeding aphid. Plant Physiol 134:420-431

Zulpa G, Zaccaro MC, Boccazzi F, Parada JL, Storni M (2003) Bioactivity of intra and extracellular substances from cyanobacteria and lactic acid bacteria on "wood blue stain" fungi. Biol Control 27:345-348

\section{Submit your manuscript to a SpringerOpen ${ }^{\circ}$ journal and benefit from:}

- Convenient online submission

- Rigorous peer review

- Open access: articles freely available online

- High visibility within the field

Retaining the copyright to your article

Submit your next manuscript at springeropen.com 